\title{
O desafio do trabalho científico no mundo contemporâneo: dinamismo, integração, ética e solidariedade
}

\author{
The challenge of scientific work in the contemporary world: dynamism, integration, \\ ethics and solidarity
}

\section{Magda Guimarães de Araújo Faria ${ }^{1 *}$ Caroliny dos Santos Guimarães da Fonseca ${ }^{2}$ Luísa Perissé ${ }^{3}$ \\ Donizete Vago Daher * Irma da Silva Brito ${ }^{5}$}

O processo de construção de uma carreira científica pode ser considerado um trabalho árduo e gradativo que requer muita determinação, pois demanda grande esforço na compreensão da pluralidade de fenômenos que envolvem a prática da pesquisa. Por outro lado, a sedução do conhecimento traz à tona desafios e embates que perpassam a construção de saberes, como a manutenção de um elevado número de publicações e a busca por inovações conceituais e metodológicas.

Tais desafios são grandemente influenciados por características contemporâneas da construção de conhecimento $^{(1)}$, como por exemplo, ubiquidade da informação e da educação ${ }^{(2)}$, o que se traduz em uma redução do período de vigência de conceitos orientadores, movimento intitulado por Thomas Kuhn ${ }^{(3)}$ como "revoluções científicas", no qual ocorrem frequentes mudanças paradigmáticas sobre determinado assunto. Não obstante a isso, a globalização do saber aponta também para a possibilidade de pesquisadores trabalharem em rede, em um movimento dinâmico, integrador e desafiador.

O dinamismo aliado à construção do conhecimento científico indica a disponibilidade do pesquisador em abraçar novos objetos de pesquisa e perspectivas teóricas que possam gerar produtos de impacto para a população, fugindo, dessa forma, da ciência intangível, criada por poucos e inacessível para muitos.

O aspecto integrador da construção do conhecimento na perspectiva contemporânea indica a incorporação de um número cada vez maior de temáticas que abarquem necessidades coletivas, em que as possibilidades metodológicas estão cada dia mais relacionadas à inclusão do público-alvo enquanto agente

\footnotetext{
${ }_{1}^{1}$ Pós-doutorado pela UERJ/Universidade de Coimbra. Doutora em Enfermagem. Professora Adjunta do Departamento de Enfermagem em Saúde Pública da Faculdade de Enfermagem da Universidade do Estado do Rio de Janeiro

${ }^{2}$ Mestranda em Bioética e Ética Médica na Universidad Européa del Atlántico da Espanha. Especialista em Gestão em Enfermagem, Urgência e Emergência e Auditoria em Sistemas de Saúde.

${ }^{3}$ Especialista em Enfermagem do Trabalho pela Universidade Federal do Rio de Janeiro e Clínica Médica e Cirúrgica nos Moldes de Residência pela Universidade Federal do Estado do Rio de Janeiro e em Neonatologia pela Universidade Veiga de Almeida.

${ }^{4}$ Especialista em Enfermagem do Trabalho pela Universidade Federal do Rio de Janeiro e Clínica Médica e Cirúrgica nos Moldes de Residência pela Universidade Federal do Estado do Rio de Janeiro e em Neonatologia pela Universidade Veiga de Almeida.

${ }^{5}$ Doutora em Enfermagem. Professora coordenadora do Departamento de Enfermagem Comunitária da Escola Superior de Enfermagem de Coimbra
} 
co-participante e transformador, principalmente nas pesquisas sociais realizadas pela Enfermagem e por outras áreas de conhecimento.

Não obstante às características processuais da construção do conhecimento, para o êxito deste processo deve-se ressaltar a necessidade de adequar a aspetos da dimensão humana, a citar: a ética e a solidariedade.

A ética na construção de conhecimento é comumente associada às experiências com seres humanos, entretanto, pouco se fala da ética interpessoal. Tal dimensão é perceptível no respeito ao trabalho do outro, realizando-se assim, a devida referência ao que já foi publicado sobre uma temática específica e a aproximação aos grupos que trabalhem o mesmo eixo temático. Ressalta-se que a ética que pensamos inerente ao ser humano vem esgarçando-se no campo da construção do conhecimento, mas continuamos a defendê-la como imprescindível no mundo contemporâneo, no qual publicações virtuais são tão frequentes quanto os casos de apropriação intelectual indevida.

Mas da ética interpessoal, poderemos ainda somar a dimensão da solidariedade. Esta deve ser observada e enfatizada entre os pesquisadores e, principalmente, no contexto institucional. A solidariedade tem a função de manter a coesão social, ou seja, o apoio profícuo entre os indivíduos que, quando se fala de produção do conhecimento, é um fator potenciador. É dever do pesquisador estar em constante movimento de atualização e de qualificação profissional, de estar disponível para a partilha com os seus pares e, cabe as instituições de ensino e de pesquisa o fomento e apoio necessário para realização destas atividades.

Diante disso, observa-se que o "fazer ciência" é influenciado por inúmeros e complexos fatores que podem ter relação processual ou humana. É necessária a incorporação destas dimensões para que o pesquisador se adeque às necessidades oriundas do mundo contemporâneo e possa, de fato, contribuir e construir conhecimento válido e útil para a sociedade.

\section{REFERÊNCIAS}

1. Faria MGA, Acioli S, Taborda M, Gallasch $\mathrm{CH}$. Aspectos contemporâneos da construção compartilhada do conhecimento: uma perspectiva virtual. Rev Min Enferm. 2018[citado em 14 dez 2018];22:e-1089. Disponível em: DOI: $10.5935 / 1415-2762.20180019$

2. Santaella L. Desafios da ubiquidade para a educação. Ensino Superior Unicamp, 2013 [citado em 14 dez 2018]; 9:19-28. Disponível em: https://www.revistaensinosuperior.gr.unicamp.br /edicoes/edicoes/ed09_abril2013/NMES_1.pdf

3. Kuhn T. A estrutura das revoluções científicas. 5. ed. São Paulo: Editora Perspectiva S.A; 1997. 